Alcileide Cabral do Nascimento

Universidade Federal Rural de Pernambuco, Recife, PE, Brasil

\title{
A primavera feminista. Vozes de luta da emancipação feminina no Brasil e Uruguai
}

Era primavera de 2016, sol e brisa a iluminar e arejar a minha nova pesquisa, que se iniciava no Arquivo Nacional, na bela e contrastante cidade do Rio de Janeiro. Começava a enveredar por um tema pouco conhecido pela historiografia sobre o feminismo no Brasil: a conquista do direito ao voto pelas mulheres no Rio Grande do Norte em 1927. Como sentenciou o jornal O Paiz (1927), depois desse acontecimento, o feminismo ia mesmo de "vento em popa". Em meio a jornais, correspondências, fotos, poesias e tantos fragmentos desse momento sobre a terra potiguar e suas mulheres, muitas outras vozes, ruídos, cores, cenas de luta, de subversão, de conquista, de decepção, de derrotas, de vitórias de várias outras mulheres, feministas, escritoras, professoras, advogadas, pintoras, me cercavam e vinham de diferentes lugares, cidades e estados desse imenso país.

O contato com os arquivos, com as fontes de pesquisa, somado às leituras e pesquisas anteriores, me dava a nítida convicção de que uma parte das mulheres brasileiras não estava conformada com o seu confinamento ao lar e com a sua subalternidade. Queriam mais! Em diferentes lugares, criticavam as dificuldades de acesso às universidades, aos empregos públicos, à educação básica, às interdições à sua participação na política partidária, e começavam a questionar que República era essa que só considerava os homens como cidadãos!

Foi dessa "conversa" com as mulheres, feministas ou não, que nasceu a ideia de reunir as pesquisas dispersas em vários estados brasileiros para compor um painel regional e nacional sobre a ação das mulheres, suas formas de luta, reivindicações, práticas e os diversos questionamentos sobre o que é ser mulher, lastro também a construção de novas subjetividades que vão surgindo no último quartel do século XIX. Ao mesmo tempo, era preciso descentrar o olhar historiográfico do Sudeste para visualizar o Brasil, descontruindo, portanto, a metáfora da "primeira onda do feminismo", que pressupõe a subalternidade de uma região sobre as outras, de que as lutas feministas tinham surgido originariamente no

\section{(c) (7)}

Esta obra está sob licença Creative Commons. 
Sudeste e, só depois, se estendido para outras capitais e estados. Assim, ao contemplar outras regiões com estudos e/ou pesquisas que têm como foco a atuação das mulheres na imprensa, nas revistas, nos movimentos feministas, pretendemos compreender melhor a diversidade de enunciados sobre a mulher que ressignificam seu lugar social e político, ouvindo as "vozes" femininas que não quiseram mais perecer no silêncio.

A Revista Estudos Feministas (REF) encampou a ideia, e, a partir daí, conseguimos, a Profa. Rachel Soihet e eu, mobilizar o/as pesquisadores/as brasileiro/as para um painel que se ampliou com a participação de pesquisadores/as uruguaios. Afinal, o debate sobre a cidadania feminina era amplo, alcançando a América do Sul, do Norte e o continente europeu. Nas primeiras décadas do século XX, é possível falar de um feminismo transnacional e internacional tecido em redes e organizações diversas, unindo mulheres na luta por direitos, justiça e inclusão política e social. As mulheres, feministas ou não, em sua maior parte pertencentes a um extrato da elite branca e intelectualizada, estavam em diferentes países promovendo o debate e refletindo sobre sua condição de subalternidade frente aos homens. A seção temática, imbuída com esse intuito, apresenta a atuação das mulheres e dos movimentos feministas no Brasil e no Uruguai que questionaram a democracia liberal, a interdição dos direitos políticos para as mulheres, as condições de trabalho, as desigualdades nas relações de gênero e lutaram pela cidadania feminina. Cabe agradecer à REF, que apoiou essa ideia; o/as pesquisador/as, que trouxeram as vozes de luta, de insubordinação das mulheres de diferentes regiões do Brasil, bem como à rede de pareceristas mobilizadas para ler acuradamente cada artigo enviado. Por diferentes razões, alguns trabalhos não foram contemplados, mas fica o agradecimento da participação nesse esforço coletivo.

O primeiro artigo, de Eliane Martins e Paulo Brito, discute a emancipação feminina nos sertões goianos em fins do século XIX, visando compreender como os espaços de instrução e leitura, existentes na antiga capital goiana (Goiás), na segunda metade do século XIX e no início do século XX, foram (re)apropriados por algumas mulheres vilaboenses de forma a lhes garantir a expressão de suas experiências. Para tanto, partindo da documentação do Gabinete Litterario Goyano, criado em 1864, o/as autores/as s buscaram, por meio do protagonismo de Silvina Ermelinda Xavier de Britto e Jacintha Luiza do Couto Brandão Peixoto, compreender questões em torno da instrução das mulheres, de seu exercício de leitura, de um ensaio de emancipação representado pelos pedidos de voto das goianas em 1889 e das táticas manejadas por essas mulheres na expectativa de exercitar sua intelectualidade, ainda que lhes fosse apresentado como um caminho cheio de obstruções.

Mônica Karawejczyk tem como objetivo analisar os passos iniciais da Federação Brasileira para o Progresso Feminino, associação feminista fundada em 1922 pela jovem bióloga Bertha Lutz, e a Primeira Conferência pelo Progresso Feminino, demonstrando a importância desse evento para a definição de estratégias de ação que orientaria a Federação. Os debates e temas da Conferência permitem compreender como o feminismo transborda as fronteiras locais, conectando mulheres em organizações nacionais e internacionais, alinhando ações na luta pela emancipação feminina. Embora Bertha Lutz tenha sido exitosa na construção de uma imagem de um feminismo "bem-comportado" no Brasil, ao questionar, e não se sujeitar aos lugares determinados para seu sexo, rompe com a cultura patriarcal e torna "incendiária" a pauta feminista defendida na Federação.

É nesse lastro de inquietações e debates sobre a cidadania feminina que investigo a importância da Cruzada Feminista Brasileira - organização pernambucana criada por Martha de Hollanda em 1931 - e como o movimento feminista nasce cindido em Pernambuco, já que havia a Federação Pernambucana para o Progresso Feminino, filiada à Federação Nacional. A partir das estratégias da Cruzada, procuro compreender a construção de uma 
nova cultura política feminista em que as mulheres debatem na imprensa a desigualdade de gênero, defendem direitos políticos igualitários e constroem sua visão de mundo. Assim, tem relevância estratégica o uso dos jornais pelas feministas como principal veículo de comunicação de massa, no momento em que se instituíam o sujeito feminino do direito e a opinião pública por meio dos periódicos. As feministas expandiram as exigências da equidade, questionaram as diferentes assimetrias da República liberal e pouco democrática, contestaram a naturalização da diferença entre os sexos e lutaram pela ampliação da cidadania e da democracia em solo pernambucano, em sincronia com o debate nacional e internacional. Do legado dessas lutas feministas, pouco conhecido na História, todas nós somos beneficiárias.

Por fim, como o feminismo é transnacional, temos uma narrativa sobre a luta das mulheres pela cidadania política no Uruguai com o artigo de Maria Laura Vazquez e Alvaro García, que analisam o contexto histórico centrado nas discussões sobre os diferentes posicionamentos na aprovação dos direitos políticos das mulheres no Uruguai dos anos 1920 e 1938. No processo de consolidação do Uruguai como "país modelo" criado sob a égide do batllismo, se apresentavam como principais instrumentos os partidos políticos, que veiculavam as mudanças em função de seus interesses eleitorais e políticos específicos. Nas discussões sobre os valores que caracterizavam o Uruguai, o tema dos direitos políticos das mulheres esteve presente. Os partidos tomaram como um dos eixos dessa consolidação democrática e social, as mulheres como objeto político. Como dizem o/as autores/as: "Las opiniones oscilaban entre los cambios radicales y graduales, los nuevos roles que destruían los valores tradicionales y la organización familiar tradicional e incluso, las virtudes y valores morales que la "naturaleza" había dado a cada uno de los sexos". Aqui, como lá, a vitória do voto feminino parecia ser terreno movediço, provisório e instável.

Com essas pesquisas, lançam-se luzes sobre a importância das mulheres e dos movimentos feministas na luta pela ampliação da cidadania nas democracias liberais e conservadoras, nas primeiras décadas dos regimes republicanos, bem como sobre a constituição de uma cultura política feminista e uma forma de ver o mundo na perspectiva das mulheres. Convido todo/as para "ouvir" essas histórias pouco conhecidas de mulheres de luta e de fibra.

\section{Referência}

O Paiz. Rio de Janeiro, 6 de nov. 1927. p. 3.

[Recebido em 22/05/2018

e aceito em 23/05/2018]

Alcileide Cabral do Nascimento (alcileide.cabral@gmail.com) é pós-doutorada pela UNICAMP (SP - 2011) e Universidade Federal Fluminense, (UFF - 201 7), doutorou-se em História pela Universidade Federal de Pernambuco (2006). Seus temas de pesquisa atuais são: História do Movimento Feminista; Feminismos; Relações de Gênero; Maternidade; Infância e Políticas Públicas para Infância. Coordena o Grupo de Pesquisas e Estudos em Gênero (Nupege/UFRPE); integra o Gt Nacional de Relações de Gênero e o GT Infância e Juventude/ANPUH PE. 